\title{
Neurokinins Activate Local Glutamatergic Inputs to Serotonergic Neurons of the Dorsal Raphe Nucleus
}

Rongjian Liu, Ph.D., Yuqiang Ding, Ph.D., and George K. Aghajanian, M.D.

It has been proposed that antidepressant effects of neurokinin $\mathrm{NK}_{1}$ receptor blockade may result from an increase in serotonin (5-HT) transmission. However, the mechanism by which neurokinins influence 5-HT neurons is not known. In this study, local $\mathrm{NK}_{1}$ and $\mathrm{NK}_{3}$ receptor-mediated responses in 5-HT neurons of the dorsal raphe nucleus (DRN) were studied using intracellular recording in rat brain slices. Bath application of the $N K_{1}$ receptor agonist substance $P(S P)$ or the $\mathrm{NK}_{3}$ receptor agonists senktide and NKB induced a robust increase in "spontaneous" excitatory postsynaptic currents (EPSCs) in 5-HT neurons. The EPSCs were blocked by the AMPA/kainate glutamate receptor antagonist $C N Q X$ and the fast $\mathrm{Na}^{+}$channel blocker tetrodotoxin (TTX), indicating that the increase in EPSCs resulted from an increase in impulse flow in local glutamatergic neuronal afferents. The neurokinins agonists had no direct excitatory effects on 5-HT neurons and no $\mathrm{NK}_{1}$ or $\mathrm{NK}_{3}$ receptor immunolabeling was found in 5-HT-labeled neurones. However, neurokinins, by increasing excitatory postsynaptic potentials (EPSPS), did increase the spiking of 5-HT neurons. The SP- and NKB-induced EPSCs were preferentially blocked by $\mathrm{NK}_{1}$ and $\mathrm{NK}_{3}$ antagonists, and there was minimal cross-desensitization between agonists at the two receptors. We conclude that neurokinins, via distinct $\mathrm{NK}_{1}$ and $\mathrm{NK}_{3}$ receptors, could promote 5-HT transmission, at least in part, by exciting a local population of glutamatergic inputs to 5-HT neurons in the DRN. However, these local excitatory effects, viewed within the context of the global effects of neurokinins on 5-HT neurons, reveal important differences between the functional role of $\mathrm{NK}_{1}$ and $\mathrm{NK}_{3}$ receptors.

[Neuropsychopharmacology 27:329-340, 2002] (C) 2002 American College of Neuropsychopharmacology. Published by Elsevier Science Inc.
KEY WORDS: Neurokinin; Serotonin; Raphe; Glutamatergic neuron; EPSC; $N K_{1}$ receptors; $N_{3}$ receptors

Members of the tachykinin (neurokinin) family of neuropeptides, including substance $\mathrm{P}(\mathrm{SP})$, neurokinin A

From the Departments of Psychiatry and Pharmacology, Yale School of Medicine, New Haven, CT 06508, (RL, GKA), Institute of Neuroscience, Fourth Military Medical University, Xi'an 710032, P.R. China (YD).

Address correspondence to: Dr. G.K. Aghajanian, Department of Psychiatry, Yale School of Medicine/CMHC, 34 Park Street, New Haven, CT, 06508. Tel.: (203) 974-7761; Fax: (203) 974-7897; E-mail: george.aghajanian@yale.edu

Received September 11, 2001; revised January 16, 2002; accepted February 8, 2002.

Online publication: 2/11/02 at www.acnp.org/citations/ Npp021102243.
(NKA), and neurokinin B (NKB), have been investigated extensively as putative excitatory neurotransmitters/modulators in the central nervous system. The physiological effects of neurokinins are mediated by three distinct receptors, $\mathrm{NK}_{1}, \mathrm{NK}_{2}$ and $\mathrm{NK}_{3}$ (Nakanishi 1991; Regoli et al. 1994; Seabrook et al. 1995). Although all three endogenous neurokinins can interact with multiple neurokinin receptors, SP is a preferential agonist at the $\mathrm{NK}_{1}$ receptor, whereas $\mathrm{NKB}$ is the presumed endogenous agonist at the $\mathrm{NK}_{3}$ receptor (Horwell 1995; Iversen et al. 1990; Maggi et al. 1993; Stables et al. 1994; Culman and Unger 1995). Neurokinins have been implicated in the pathophysiology of anxiety and depression by variety preclinical and clinical studies (for review see Stout et al. 2001). A recent clinical study 
reported an antidepressant effect after chronic treatment with an antagonist of central $\mathrm{NK}_{1}$ receptors (Kramer et al. 1998). The prospect of neurokinin receptor antagonists as novel therapeutic agents is intriguing, but clearly further study is needed to define the range of clinical applicability of these agents.

Recently, based on studies in $\mathrm{NK}_{1}$ receptor knockout mice, it has been suggested that the antidepressant action of $\mathrm{NK}_{1}$ receptor inactivation may result from an increase in central 5-HT neurotransmission through desensitization of $5-\mathrm{HT}_{1 \mathrm{~A}}$ autoreceptors (Froger et al. 2001). Current pharmacological treatment of depression frequently employs selective serotonin reuptake inhibitors, which are also known to desensitize $5-\mathrm{HT}_{1 \mathrm{~A}}$ autoreceptors (Chaput et al. 1986). Additionally, there are a number of studies showing behavioral and neurochemical interactions between the 5-HT system and various neurokinins. Intracisternal administration of the $\mathrm{NK}_{3}$ agonist senktide results in a complex behavioral syndrome involving multiple 5-HT receptors and is dependent upon intact stores of endogenous 5-HT (Stoessl et al. 1987; Stoessl et al. 1990). These studies imply that neurokinins may induce 5-HT-mediated behaviors by enhancing the release of endogenous 5-HT. The 5-HT cell bodies located in the dorsal raphe nucleus (DRN) and the median raphe nucleus (MRN) give rise to the principal 5-HT projections to the forebrain. There are a number of studies showing that local injections of neurokinins into the raphe nuclei increase 5-HT release and 5-HT mediated behaviors. For example, injection of SP into the MRN induces an increase in 5-HT turnover in the hippocampus (Forchetti et al. 1982). Similarly, local injection of SP into the DRN increases extracellular levels of 5-HT in the ventral hippocampus of rats (Gradin et al. 1992). On a behavioral level, infusion of the selective $\mathrm{NK}_{3}$ agonist senktide or a SP analog into the MRN induces a 5-HT-dependent increase in locomotor activity (Paris and Lorens 1987; Paris et al. 1989). It should be noted that there are differential effects of local versus intracisternal administration of SP. While the injection of SP directly into the raphe nuclei leads to an increase in 5-HT-mediated behaviors, intracisternal administration of SP fails to elicit 5-HT-mediated behaviors (Stoessl et al. 1987). In contrast, the $\mathrm{NK}_{3}$ agonists strongly elicit 5-HT-mediated behaviors both after local injection into the raphe and after intracisternal administration. These studies indicate that there are important differences between the local and global effects of activating $\mathrm{NK}_{1}$ versus $\mathrm{NK}_{3}$ receptors.

Surprisingly, there have been no electrophysiological studies characterizing the local effects of neurokinin agonists on the activity 5-HT neurons. The purpose of this study was to investigate the effects of not only SP ( $\mathrm{NK}_{1}$ receptor agonist) but also $\mathrm{NK}_{3}$ receptor agonists upon 5-HT neurons in a DRN brain slice preparation. Both, SP and NKB immunoreactive nerve fibers and ter- minals have been detected in the DRN (Cuello and Kanazawa 1978; Marksteiner et al. 1992). In situ hybridization studies show that there are $\mathrm{NK}_{1}$ receptor mRNA-positive neurons in the periaqueductal gray and DRN (Maeno et al. 1993) and $\mathrm{NK}_{3}$ receptor mRNApositive neurons in various raphe nuclei, including the DRN (Ding et al. 1996; Mileusnic et al. 1999). However, it has been reported recently that $\mathrm{NK}_{1}$ receptors in the DRN are located on non-5-HT neurons rather than 5-HT neurons (Froger et al. 2001). Therefore, we not only investigated direct effects on 5-HT neurons but examined possible indirect effects of neurokinins that may be mediated through non-5-HT neurons. In parallel with the electrophysiology, immunocytochemical methods were employed to determine whether $\mathrm{NK}_{3}$ as well as $\mathrm{NK}_{1}$ receptors are located upon 5-HT or non-5-HT cells.

\section{MATERIALS AND METHODS}

\section{Brain Slice Preparation}

Brain slices were prepared as described previously (Jolas and Aghajanian 1996). Briefly, male albino rats (130$180 \mathrm{~g}$, Harlan) were anesthetized with chloral hydrate ( $400 \mathrm{mg} / \mathrm{kg}$, i.p.), in adherence to protocols approved by the Yale University Animal Care and Use Committee. Following decapitation, the brains were removed rapidly and trimmed in ice-cold $\left(\sim 4^{\circ} \mathrm{C}\right)$ artificial cerebrospinal fluid (ACSF) in which sucrose $(252 \mathrm{mM})$ was substituted for $\mathrm{NaCl}$ (sucrose-ACSF). A block of tissue containing the DRN was dissected and coronal slices $(600 \mu \mathrm{M})$ were cut in sucrose-ACSF with an oscillatingblade tissue slicer (DSK Microslicer, Ted Pella. Inc., Redding California). A slice containing the DRN was positioned on the stage of a fluid-gas interface chamber with the cerebral aqueduct facing an elevated fluid inlet. Fluid was wicked directly from the elevated inlet onto the slice as previously described (Burlhis and Aghajanian 1987). The standard ACSF ( $\mathrm{pH} \sim 7.35$ ), equilibrated with $95 \% \mathrm{O}_{2} / 5 \% \mathrm{CO}_{2}$, contained: $\mathrm{NaCl}$, $128 \mathrm{mM} ; \mathrm{KCl}, 3 \mathrm{mM} ; \mathrm{CaCl}_{2}, 2 \mathrm{mM} ; \mathrm{MgSO}_{4}, 2 \mathrm{mM}$; $\mathrm{NaHCO}_{3}, 24 \mathrm{mM} ; \mathrm{NaH}_{2} \mathrm{PO}_{4}, 1.25 \mathrm{mM}$; and D-glucose, $10 \mathrm{mM}$. The slices were incubated at $33.0 \pm 0.5^{\circ} \mathrm{C}$ and perfused at a rate of $\sim 1 \mathrm{ml} / \mathrm{min}$. A 2-3 h recovery period was allowed before collecting data. Drug solutions, in gassed ACSF, were introduced through a stopcock arrangement to the recording chamber with a latency of $\sim 20$ s.

\section{Intracellular Recordings}

Microelectrodes were pulled from filament-containing $1.5 \mathrm{~mm}$ glass tubing using a Brown-Flaming pipette puller (Sutter Instrument Co., Novato, CA) and filled with $2 \mathrm{M} \mathrm{KCl}(30-45 \mathrm{M} \Omega$ ). Current-clamp and voltageclamp recordings were made using an AxoClamp 2A 
amplifier coupled to a pClamp/Digidata 1200 system (Axon Instruments Foster City, CA). In current-clamp mode, using $\mathrm{KCl}$-containing electrodes, putative serotonergic neurons were recognized by their long spike duration ( $1 \mathrm{msec}$ at $50 \%$ spike amplitude) and high input resistance. Previously, using a double-labeling method, neurons with these characteristics were shown to be serotonergic (Aghajanian and VanderMaelen 1982). In addition, neurons with these characteristics were shown to respond to applied 5-HT $(100 \mu \mathrm{M})$ with a hyperpolarization $\geqslant 5 \mathrm{mV}$ (Aghajanian and Lakoski 1984).

In voltage clamp, all experiments were performed using the discontinuous single-electrode voltage-clamp mode at sampling frequencies of $5-6 \mathrm{kHz}$ and a loop gain $10 \mathrm{nA} / \mathrm{mV}$ (30\% duty cycle). The headstage voltage was monitored continuously to ensure that voltage transients decayed fully before voltage was sampled; false clamping was avoided by optimizing the capacitance compensation and selecting sampling frequencies that allowed input voltage to settle to a horizontal baseline. Postsynaptic currents were measured in discontinuous single-electrode voltage clamp mode $(10 \mathrm{kHz}$ low pass filter cut-off frequency) and cells clamped near their resting potential $(-70 \mathrm{mV})$. With $\mathrm{KCl}$ electrodes, spontaneous inhibitory postsynaptic currents (IPSCs) and excitatory postsynaptic currents (EPSCs) both appear as inward currents because the reversal potential for chloride is shifted from approximately $-70 \mathrm{mV}$ to $-15 \mathrm{mV}$. To isolate EPSCs from reverse IPSCs, we first applied neurokinins to determine whether they induced synaptic currents. If this was confirmed, the subsequent experiments were done in presence of bicuculline $(10 \mu \mathrm{M})$ to block IPSCs. Using pClamp 8.0 (Axon Instruments), the effects of drugs on spontaneous and neurokinin-induced EPSCs were sampled by recording 10 one second episodes before and during the peak of action of the drugs.

The firing activity of 5-HT cells in anesthetized rats in vivo is dependent on a tonically active noradrenergic system (Gallager and Aghajanian 1976; Baraban et al. 1978). In brain slices, noradrenergic inputs are severed and 5-HT cells are usually quiescent; activity can be restored with the $\alpha_{1}$-adrenergic agonist phenylephrine (PE) (VanderMaelen and Aghajanian 1983). Thus PE (3 $\mu \mathrm{M})$ was added to the perfusion medium to maintain the firing of 5-HT neuron when testing the effect of neurokinins on the spiking activity of 5-HT neurons.

\section{Immunocytochemistry}

Animals and Tissue Preparation. Four rats were deeply anesthetized with sodium pentobarbital $(60$ $\mathrm{mg} / \mathrm{kg}$; i.p.), and then perfused through the heart with $100 \mathrm{ml}$ of normal saline followed by $500 \mathrm{ml}$ of $4 \%$ freshly depolymerized paraformaldehyde in $0.1 \mathrm{M}$ phosphate buffer, pH 7.4 (PB). The brain stem was removed and $30-\mu \mathrm{m}$ thick transverse serial sections were cut though the midbrain on a Vibratome and collected in PB. Alternate sections were divided into three sets, each extending from the anterior to posterior aspect of the DRN. The separate sets of the sections (about 10 stions/set) were then double stained for $\mathrm{NK}_{1}+5 \mathrm{HT}$, $\mathrm{NK}_{3}+5-\mathrm{HT}$, or $\mathrm{NK}_{1}+\mathrm{NK}_{3}$.

\section{Double Immunofluorescence Labeling for 5-HT and NK Receptors $\left(\mathrm{NK}_{1}\right.$ and $\mathrm{NK}_{3}$ )}

The sections were processed for 5-HT immunofluorescence staining using the TSA (Tyramide Signal Amplification) method, and then for $\mathrm{NK}_{1}$ or $\mathrm{NK}_{3}$ staining with routine immunofluorescence staining. This method is optimal for performing double immunofluorescence staining when both primary antibodies are raised in the same species (Shindler and Roth 1996). Briefly, after treatment with blocking buffer, the sections were incubated overnight in rabbit anti-5-HT IgG $(160,000$; DiaSorin, Stillwater, MN), biotinylated donkey anti-rabbit IgG (1:200; Jackson) for $2 \mathrm{~h}$, streptavidin-horseradish peroxidase (1:100) for $1 \mathrm{~h}$, and then FITC-tyramide (1:100) in amplification diluent for $8 \mathrm{~min}$. With the dilution, no signal was detected unless amplified with TSA Kit. After being washed in PBS, the sections were incubated overnight with the second primary antibody, rabbit anti-NK ${ }_{1} \operatorname{IgG}$ (1:4,000; Advanced Targeting System) or rabbit anti-NK ${ }_{3} \operatorname{IgG}(1 \mu \mathrm{g} / \mathrm{ml}$; Ding et al. 1996), and then with Cy3-conjugated secondary antibody (1:200; Jackson) for $2 \mathrm{~h}$. The sections were washed, mounted onto glass slides, coverslipped, and observed under the confocal microscope for image acquisition and initial processing. Immunohistochemical controls included omitting the primary antibody and replacing the secondary antibody with normal serum from the same species. To control for possible cross-reaction between the first primary antibody and the second secondary antibody, the sections were processed as described above except that the second primary antibody (rabbit anti-NK $\mathrm{NK}_{1}$ or $\mathrm{NK}_{3} \operatorname{IgG}$ ) was omitted. Thus, the sections incubated with the first primary antibody and revealed with FITC-TSA were incubated with Cy3-conjugated donkey anti-rabbit antibody. The sections were uniformly negative on the red channel.

\section{Drugs}

Tetrodotoxin (TTX) was obtained from Alomone Labs (Jerusalem, Israel); 5-hydroxytryptamine creatinine sulfate (5-HT) was from Sigma, bicuculline methiodide (Bic), substance $P$, senktide, neurokinin $B$, 6-cyano7-nitroquinoxaline-2,3-dione (CNQX) were from Research Biochemical International (Natick, MA); RP 67580 was from Rhone-Poulenc Rorer (Cedex, France) and SB 223412 was from SmithKline Beecham Pharmaceuticals (Harlow, Essex, Italy). 


\section{Analysis and Statistics}

EPSCs were acquired by the Clampex module of pClamp 8 and a Digidata 1200 interface. Analysis of PSCs frequency and amplitude was conducted with Mini Analysis software (Synaptosoft Inc, Decatur, GA). This program detects and measures spontaneous synaptic events according to amplitude, rate of rise, duration, and area under the curve (fc). Analysis parameters were as follows: amplitude threshold, $5 \mathrm{pA}$ and area threshold, $75 \mathrm{fc}$. Statistical comparisons of the extracted amplitude and interspike interval distributions for EPSCs were conducted with the nonparametric Kolmogorov-Smirnov (K-S) test. This test gives a measure of the relative dispersion between two distributions (Goodman 1954). Cumulative probability distributions were considered significantly different with $p<.01$ (K-S test). Descriptive statistics are given as mean \pm SEM Mean amplitude, frequency, and other data were analyzed by 2-tailed paired Student's $t$-test.

\section{RESULTS}

Of 285 neurons recorded in the DRN, 180 met criteria for classification as being serotonergic and these were used for the experiments with the neurokinins. These cells had the following characteristics: long spike duration (1.02 $\pm 0.02 \mathrm{msec}$ at half amplitude), an hyperpolarizing response ( $\geqslant 5 \mathrm{mV})$ to applied 5-HT $(100 \mu \mathrm{M})$, an average resting potential of $-63.2 \pm 1.6 \mathrm{mV}$, mean action potential amplitude of $91.8 \pm 1.3 \mathrm{mV}$, and high input resistance $(226.1 \pm 3.1 \mathrm{M} \Omega)$.

\section{Substance P and Senktide Have No Direct Effect on 5-HT Neurons of the DRN}

The effects of both SP and senktide on 5-HT neurons in the DRN were tested under voltage clamp. SP and senktide frequently produced an increase in spontaneous postsynaptic currents (PSCs) in 5-HT neurons, which could be blocked by the AMPA/kainate antagonist CNQX (see below). However, after giving CNQX to remove the contaminating influence of superimposed PSCs, senktide and SP had no direct effects on any of the 5-HT cells tested $(n=20)$. Because washout of CNQX is prolonged, the data from these cells were not included in the results from subsequent experiments on the induction of synaptic currents by neurokinins. Figure 1, panel A, shows a recording from a typical 5-HT neuron, which had a typical outward current and increased conductance ( $\sim 20 \%)$ in response to $100 \mu \mathrm{M} 5-\mathrm{HT}$. When senktide was bath applied $(1 \mu \mathrm{M}, 2 \mathrm{~min})$ prior to the administration of CNQX, it induced a large increase in spontaneous PSCs (arrow, Figure 1) making it difficult to assess postsynaptic changes in isolation. Follow- ing CNQX, neither senktide nor SP produced observable changes in holding current or membrane conductance.

\section{Immunolabeling Shows Lack of Co-localization of 5-HT and NK Receptors in the DRN}

Sets of sections extending from the anterior to posterior DRN were examined after treatment by each of the double staining combinations ( $\mathrm{n}=4$ rats). The distribution of 5-HT-containing in the DRN was consistent with previous studies (Dahlström and Fuxe 1964; Ungerstedt 1971). Although 5-HT-positive and $\mathrm{NK}_{1}$ and $\mathrm{NK}_{3}$ receptor-expressing neurons were intermingled in the DRN, no neurons were doubly immunostained for 5-HT and neurokinin receptors (5-HT and $\mathrm{NK}_{1}$ or 5-HT and $\mathrm{NK}_{3}$ ) (Figure 1, panel b). These observations are consistent with the electrophysiological results which failed to show any direct postsynaptic effects of $\mathrm{NK}_{1}$ or $\mathrm{NK}_{3}$ agonists upon 5-HT neurons. In addition, no $\mathrm{NK}_{1} /$ $\mathrm{NK}_{3}$ doubly-labeled neurons were found in the DRN.

\section{Substance $P$ and Senktide Induce an Increase in Spontaneous EPSCs in 5-HT Cells}

Although SP and senktide had no direct effect on 5-HT neurons both were capable of producing an increase in "spontaneous" (non-electrically evoked) PSCs (Figure 1, panel A, and Figure 2). Table 1 shows that a high proportion of 5-HT neurons exhibited PSC responses to one or both of the agonists. In the great majority of responsive cells $(91 / 104)$, SP or senktide primarily induced an increase in EPSCs as indicated by their sensitivity to CNQX $(10 \mu \mathrm{M})$ (Figure 2). However, in 10\% $(10 / 104)$ of the responsive neurons, the SP- or senktideinduced PSCs consisted of a mixture of CNQX sensitive and CNQX-insensitive PSCs. Furthermore, in three of the cells tested with SP (3/104), the PSCs were completely insensitive to CNQX but were blocked completely by application the $\mathrm{GABA}_{\mathrm{A}}$ receptor antagonist bicuculline $(10 \mu \mathrm{M})$, indicating that they were $\mathrm{GABA}_{\mathrm{A}^{-}}$ mediated IPSCs. It should be noted that EPSCs and IPSCs induced by SP or senktide also could be distinguished on the basis of time constant $(\tau)$ of decay from the peak response (not shown).

\section{Substance P and NKB-induced EPSCs Are Concentration-dependent and TTX Sensitive}

As shown in Table 2, under basal conditions spontaneous EPSC frequency and amplitude were $9.4 \pm 0.08 \mathrm{~Hz}$ and $61.1 \pm 0.04 \mathrm{pA}$, respectively. SP, senktide, or NKB significantly increased mean EPSC frequency in all responding cells (K-S test, $p<.0001, \mathrm{n}=86 / 86)$ and amplitude in most responding cells (K-S test $p<.01 \mathrm{n}=$ 51/86). Increases in EPSCs could be detected $1 \mathrm{~min}$ af- 
A.
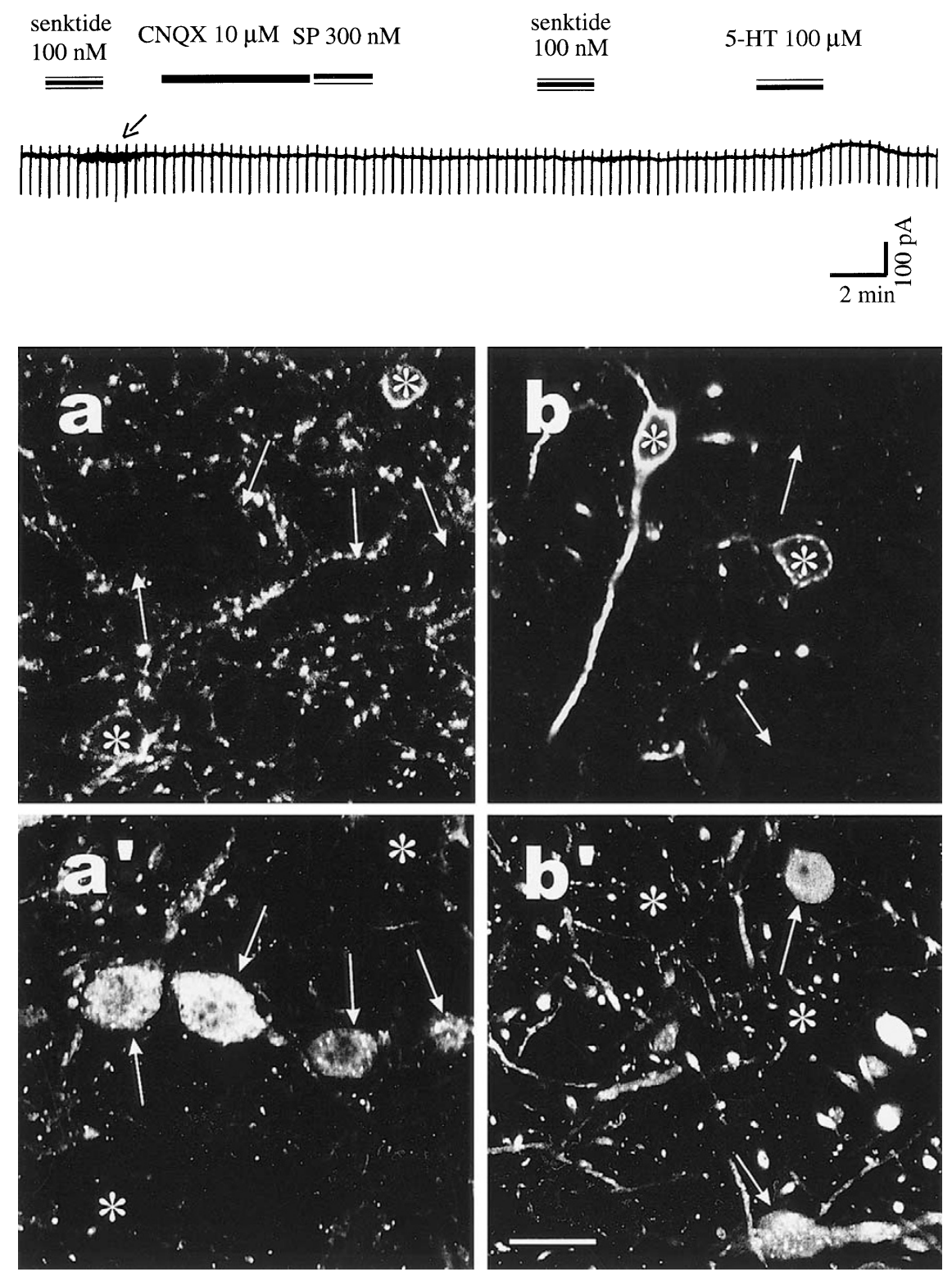

Figure 1. Lack of direct interactions between neurokinins and 5-HT cells: electrophysiological and histochemical evidence. A. Intracellular recording illustrating the lack of direct effect of a $\mathrm{NK}_{1}$ agonist SP and a selective $\mathrm{NK}_{3}$ agonist senktide on 5-HT neurons of the DRN. This intracellular voltage clamp recording from a 5-HT neuron shows a typical outward current and increased conductance in response to $100 \mu \mathrm{M} 5-\mathrm{HT}$ (right part of trace). Initially, when the $\mathrm{NK}_{3}$ agonist senktide was bath applied (1 $\mu \mathrm{M}, 2 \mathrm{~min})$, it appeared to produce no significant changes in holding current; however, because of an increase in PSCs as indicated by a thickening of the baseline trace (arrow), it was difficult to judge the exact membrane potential. After CNQX, when the PSCs were blocked, SP and senktide clearly could be seen to have no effect either on membrane potential or $R_{\text {in }}(n=20)$. $R_{\text {in }}$ was assessed by hyperpolarizing pulses applied through the recording electrode to the 5-HT neuron. (duration $400 \mathrm{~ms}$, at $20 \mathrm{~s}$ intervals). B. Confocal micrographs of double immunofluorescent staining for either $\mathrm{NK}_{1} / 5-\mathrm{HT}\left(\mathrm{a} / \mathrm{a}^{\prime}\right)$ or $\mathrm{NK}_{3} / 5-\mathrm{HT}\left(\mathrm{b}, \mathrm{b}^{\prime}\right)$ in the DRN of the rat. In both cases, no doubly labeled neurons are seen in the DRN. The absence of neurokinin receptors on 5-HT cells is consistent with the lack of direct electrophysiological effects illustrated in panel A. Arrows point to 5-HT-positive neurons. $\mathrm{NK}_{1}$ and $\mathrm{NK}_{3}$-expressing neurons are indicated by asterisks. Scale bar $=$ $40 \mu \mathrm{m}$. Double staining for $\mathrm{NK}_{1} / \mathrm{NK}_{3}$ was also performed (not shown). 
A 1
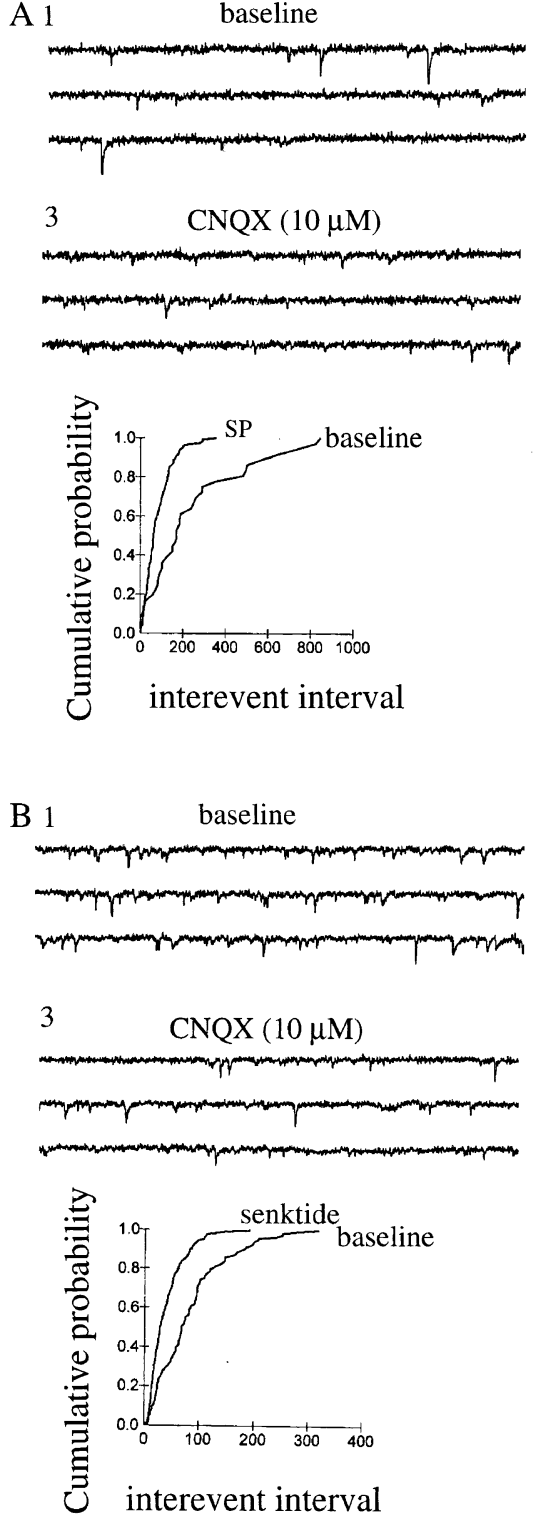

2 substance $\mathrm{P}(300 \mathrm{nM})$

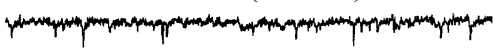

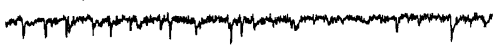

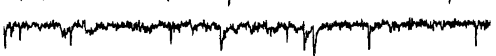

$4 \quad$ CNQX + substance P

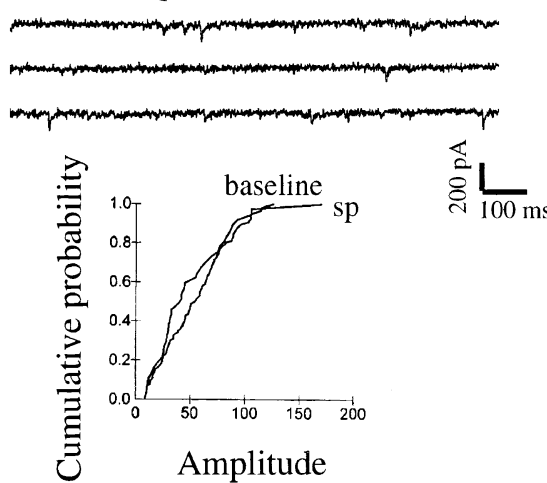

2 senktide $(100 \mathrm{nM})$

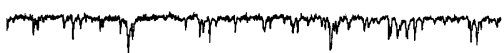

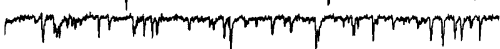

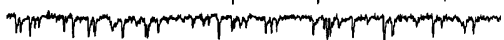

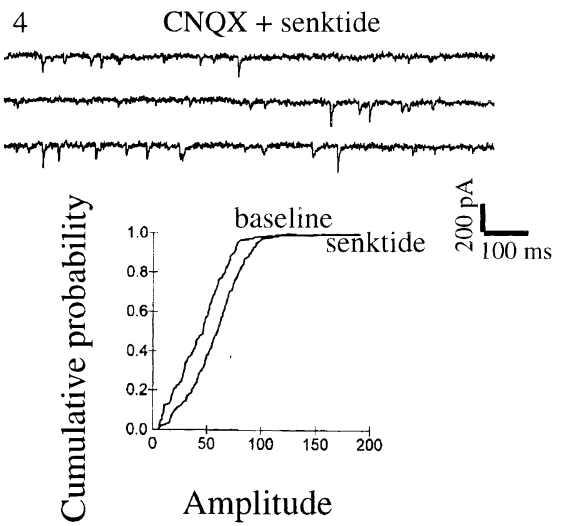

Figure 2. Induction of EPSCs by SP and senktide in 5-HT cells. A. (1-4) In voltage-clamp mode (holding potential $=$ $-65 \mathrm{mV}), \mathrm{SP}(300 \mathrm{nM})$ induced an increase in frequency of PSCs in a 5-HT cell; this effect was blocked by CNQX (10 $\mu \mathrm{M})$ indicating they were glutamatergic excitatory PSCs (EPSCs). Below are plots of normalized cumulative distributions of EPSC amplitude and frequency for this cell before and during the application of SP (data taken from ten 1-s episodes for each condition). K-S tests showed a highly significant in increase frequency $(p<$ $.01)$, but in this cell no significant change was found in amplitude. B. (14) In another cell senktide (100 nM) induced an increase in frequency of PSCs; this effect was blocked by CNQX $(10 \mu \mathrm{M})$. Below are plots of normalized cumulative distributions of EPSC amplitude and frequency for this cell before and during the application of senktide. K-S tests showed a significant increase in both for amplitude $(p<.05)$ and frequency $(p<.001)$. ter switching to the agonist-containing solution, approaching a maximum within the next 2-3 $\mathrm{min}$ and then slowly returning to the basal levels over 5-10 min. Figure 3 shows that the increases were concentrationdependent for SP $\left(\mathrm{EC}_{50} 357 \mathrm{nM}, \mathrm{n}=5\right)$ and $\mathrm{NKB}\left(\mathrm{EC}_{50}\right.$ $295 \mathrm{nM}, \mathrm{n}=5)$. The increases in EPSCs induced by SP,

Table 1. Proportion of DRN neurons in which PSCs were increased* by one, both, or neither of the neurokinins

\begin{tabular}{lc}
\hline & Number of Cells Responding (\%) \\
\hline SP and Senktide & $72 / 150(48 \%)$ \\
Senktide only & $24 / 150(16 \%)$ \\
SP only & $8 / 150(5 \%)$ \\
Neither SP nor Senktide & $46 / 150(31 \%)$ \\
\hline
\end{tabular}

$$
* \geqslant 20 \%
$$

NKB, or senktide were blocked completely by administration of the fast sodium channel blocker TTX ( $2 \mu \mathrm{M}, 8$ $\min , p<.01 \mathrm{n}=5$, Figure 4), indicating that the effects of SP or NKB were due to release of impulse-flow dependent glutamate, and not due to an increase in spontaneous quantal release (i.e. miniature EPSCs).

Table 2. Amplitude, Frequency and Decay Time $(\tau)$ of Spontaneous and Neurokinin-induced EPSCs

\begin{tabular}{lclcl}
\hline & $\begin{array}{c}\text { Frequency } \\
(\mathbf{H z})\end{array}$ & \multicolumn{1}{c}{$\begin{array}{c}\text { Amplitude } \\
(\mathbf{p A})\end{array}$} & $\begin{array}{c}\text { Decay Time } \\
(\boldsymbol{\tau})\end{array}$ & $\mathbf{n}$ \\
\hline Baseline & $9.4 \pm 0.08$ & $61.1 \pm 0.04$ & $1.05 \pm 0.03$ & \\
SP & $23.3 \pm 0.02^{* *}$ & $69.2 \pm 0.08^{*}$ & $0.67 \pm 0.05$ & 32 \\
Senktide & $30.3 \pm 0.01^{* *}$ & $78.7 \pm 0.03^{* *}$ & $0.69 \pm 0.06$ & 34 \\
NKB & $25.4 \pm 0.03^{* *}$ & $71.9 \pm 0.2^{*}$ & $0.70 \pm 0.06$ & 25 \\
\hline
\end{tabular}

$* * p<.01$.

$* p<.05$ (paired $t$-test). 


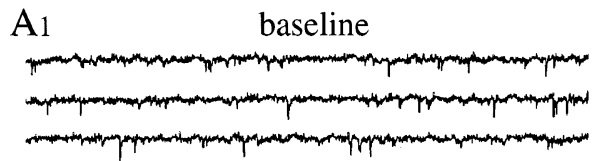

2 substance P (100 nM)

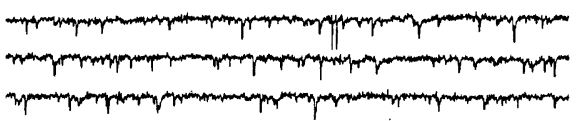

3 substance $\mathrm{P}(300 \mathrm{nM})$

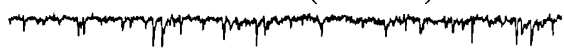

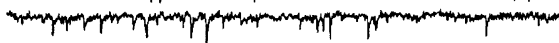

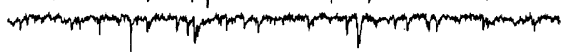

$4 \quad$ substance P $(1 \mu \mathrm{M})$
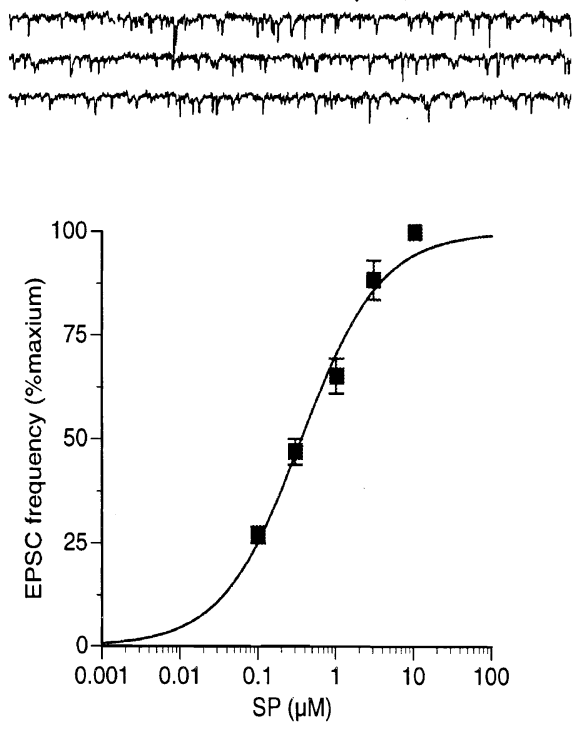

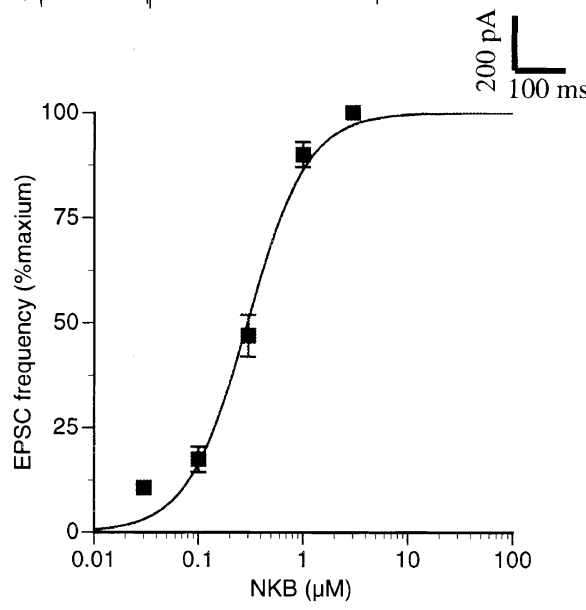

$\mathrm{B} 1$

baseline

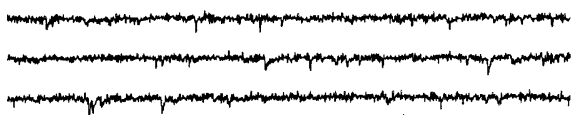

$2 \quad$ NKB $(100 \mathrm{nM})$
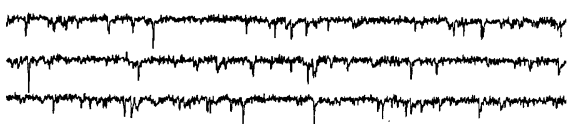

$3 \quad$ NKB (300 nM)

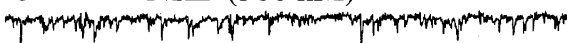

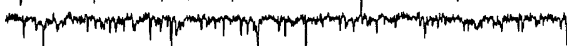

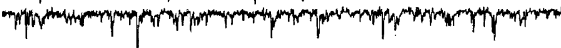

$4 \quad$ NKB $(1 \mu \mathrm{M})$

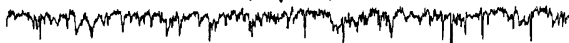

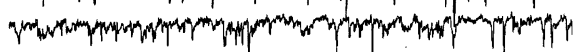

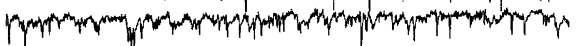

Figure 3. SP- and NKBinduced EPSCs are concentration-dependent. A. (1-4) In a 5-HT cell, EPSCs induced by SP were concentration-dependent. Below is normalized concentration-response curve for a group of five randomly selected DRN cells where the SP-induced increase in EPSC frequency at each concentration $(0.1,0.3,1,3,10 \mu \mathrm{M})$ were expressed as the percent of the $10 \mu \mathrm{M}$ SP response for each cell. The $\mathrm{EC}_{50}$ of SP was $357 \mathrm{nM}$ and a near maximally-effective concentration was $3 \mu \mathrm{M}$. B. (1-4) In another 5-HT cell, EPSCs induced by NKB were also concentrationdependent. Below is normalized concentration-response curve for a group of five randomly selected DRN cells where the NKB-induced increase in EPSC frequency at each concentration $(0.1,0.3,1$, $3,10 \mu \mathrm{M})$ were expressed as the percent of the $3 \mu \mathrm{M} \mathrm{NKB}$ response for each cell. The $\mathrm{EC}_{50}$ of NKB was $295 \mathrm{nM}$ and a near maximally-effective concentration was $1 \mu \mathrm{M}$.

\section{Pharmacological Characterization of Neurokinin- Induced EPSCs}

To determine whether the effects of neurokinin SP or $\mathrm{NKB}$ were mediated by selective activation of $\mathrm{NK}_{1}$ or $\mathrm{NK}_{3}$ neurokinin receptors, the ability of preferential non-peptide antagonists to block these effects was studied. The selective $\mathrm{NK}_{1}$ receptor antagonist RP 67580 (Fong et al. 1992; Garret et al. 1991) (10 $\mu \mathrm{M}, 25 \mathrm{~min})$ reduced the SP-induced EPSCs by $52 \%$, but had no effect on the enhancement of EPSCs by NKB. Higher concentrations (up to $30 \mu \mathrm{M}$ ) inhibited the SP effect on EPSCs by $96 \%$, while the NKB effect on EPSCs was inhibited by $52 \%$. In contrast, the selective $\mathrm{NK}_{3}$ receptor antagonist, SB 223412 (Sarau et al. 1997) (10 $\mu$ M, 25 min) reduced NKB-induced EPSC by $37 \%$, but had no effect on the enhancement of EPSCs by SP. Higher concentrations (up to $30 \mu \mathrm{M}$ ) reduced the NKB effect on EPSCs by $56 \%$, but also inhibited SP effect on EPSCs by $15 \%$. Thus, while the antagonists showed preferential blocking activation, they were not absolutely selective.

\section{Minimal Cross-desensitization Between Senktide and SP}

It has been shown that desensitization with a selective agonist can discriminate between multiple neurokinin receptors (Laufer et al. 1988). In view of the incomplete selectively of the above antagonists in blocking SP and NKB in the DRN, we turned to a cross-desensitization approach to explore further the independence of $\mathrm{NK}_{1}$ and $\mathrm{NK}_{3}$ effects in the DRN. We employed the $\mathrm{NK}_{3}$-selective agonist, senktide, which selectively and potently activates $\mathrm{NK}_{3}$ receptors in rat brain, but is virtually devoid of activity at $\mathrm{NK}_{1}$ receptors (Laufer et al. 1986a,b; 

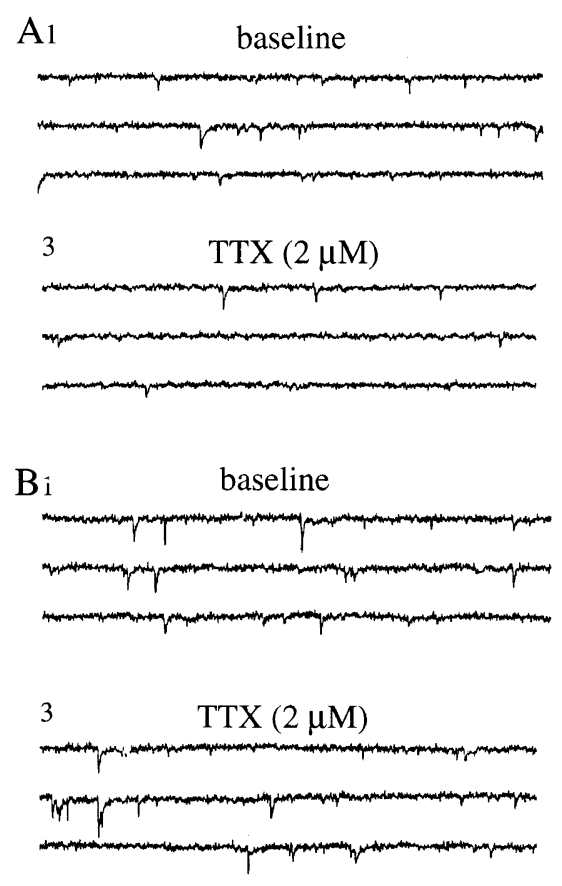

2

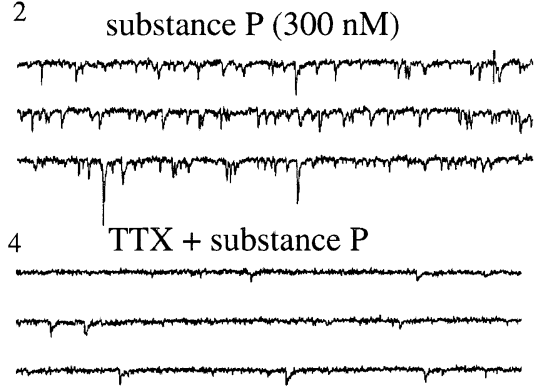

$2 \quad$ NKB $(200 \mathrm{nM})$
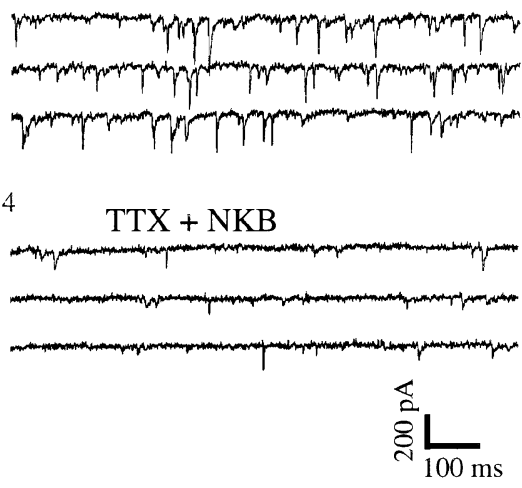

Figure 4. SP- and NKB-induced EPSCs in 5-HT cells are suppressed by bath applied TTX $(2 \mu \mathrm{M})$. A. (1-4) In a 5 -HT cell, EPSCs induced by SP (300 $\mathrm{nM}, 2 \mathrm{~min}$ ) were blocked totally by bath applied TTX (5 min). B. (1-4) In another 5-HT cell EPSCs induced by NKB (200 nM, 2 min) were blocked totally by bath applied TTX (5 $\mathrm{min}$ ).
Wormser et al. 1986). In the example shown in Figure 5, panel A, the initial application of SP $(1 \mu \mathrm{M})$ induced a strong increase in EPSC frequency in a 5-HT neuron. After washout of SP, senktide (100 $\mathrm{nM})$ also was found to induce a large initial increase in EPSC frequency. However, after continued senktide application (20 min), EPSCs were reduced to $\sim 30 \%$ of the original response. A subsequent application of SP induced a robust increase of EPSCs indicating that there is little cross-desensitization between senktide and SP. Figure 5 , panel B, summarizes data for five cells. Note that the response to SP following senktide did not exceed the original response to SP despite the elevated baseline.

\section{Neurokinin-induced excitatory postsynaptic potentials (EPSPs) Can Increase the Spiking of 5-HT Neurons}

Five 5-HT neurons that displayed strong EPSPs in response to both SP and senktide were selected for these experiments. PE $(3 \mu \mathrm{M})$ was added to the perfusate, to induce a slow, tonic level of baseline firing (see Methods). As shown in Figure 6, panel A, a slow depolarizing ramp usually preceded the triggering of spikes in the presence of PE. Under these conditions, the firing rate of all five cells was increased by $300 \mathrm{nM} \mathrm{SP}(191 \pm$ $27 \%$ ) or $100 \mathrm{nM}$ senktide $(279 \pm 34 \%)$. In the presence of senktide (Figure 6, panel B) or SP (not shown), a population of spikes emerged that were triggered by EPSPs. In presence of PE alone, only $16 \%$ of spikes were triggered by EPSPs $(n=5)$; following SP $(n=4)$ or senk- tide $(\mathrm{n}=5)$ the proportion of spikes triggered by EPSPs was increased to $59 \%$ and $64 \%$, respectively. Figure 6 , panel $\mathrm{C}$, shows that the firing induced by PE was not reduced by CNQX $(n=5)$. In contrast, the increase induced by SP or senktide was blocked by CNQX, as would be expected if it was being driven by EPSPs (Figure 6, panel $\mathrm{D}, \mathrm{n}=5$ ).

\section{DISCUSSION}

\section{Neurokinins Excite 5-HT Neurons in the DRN Indirectly by Activating a Local Population of Glutamatergic Neurons}

There are a number of studies indicating that neurokinins may induce 5-HT-mediated behaviors by enhancing the release of endogenous 5-HT (Reisine et al. 1982; Reubi et al. 1978; Solti and Bartfai 1987; Stoessl et al. 1987, 1990). It has been proposed that neurokinins may increase 5-HT release by activating 5-HT cell firing in the raphe nuclei. This proposal is based on the fact that local injections of SP into the MRN (Forchetti et al. 1982) or DRN (Gradin et al. 1992) increase 5-HT turnover or 5-HT release in terminal regions of the hippocampus. However, the mechanism by which neurokinins might alter the activity of 5-HT neurons in the DRN (or other raphe nuclei) was not delineated by those studies. The present results show that $\mathrm{NK}_{1}$ receptor agonist $\mathrm{SP}$ and the $\mathrm{NK}_{3}$ receptor agonists senktide and NKB do not have direct excitatory effects on 5-HT neurons in the 


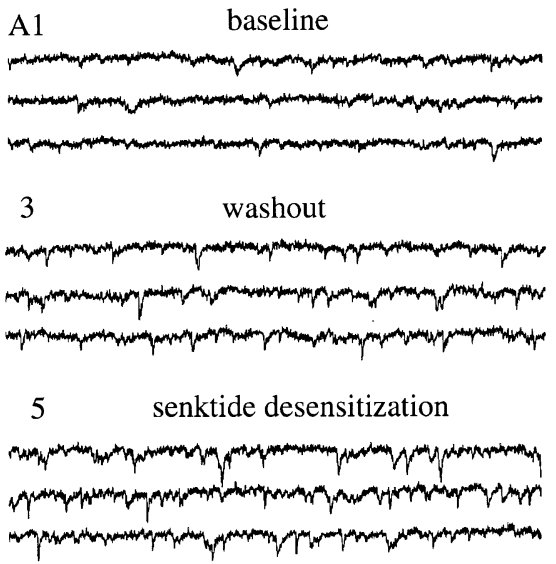

B.

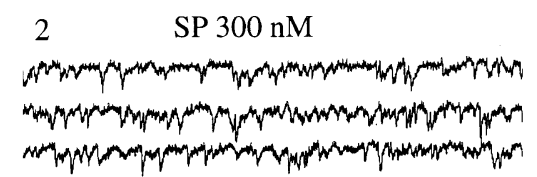

4 senktide $100 \mathrm{nM}$

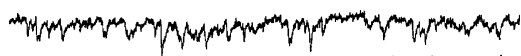

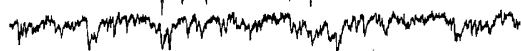

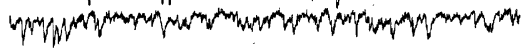

6 SP $300 \mathrm{nM}$ after senktide

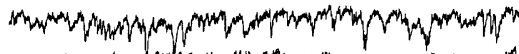

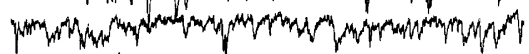

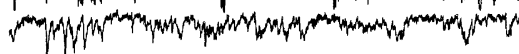

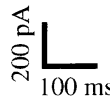

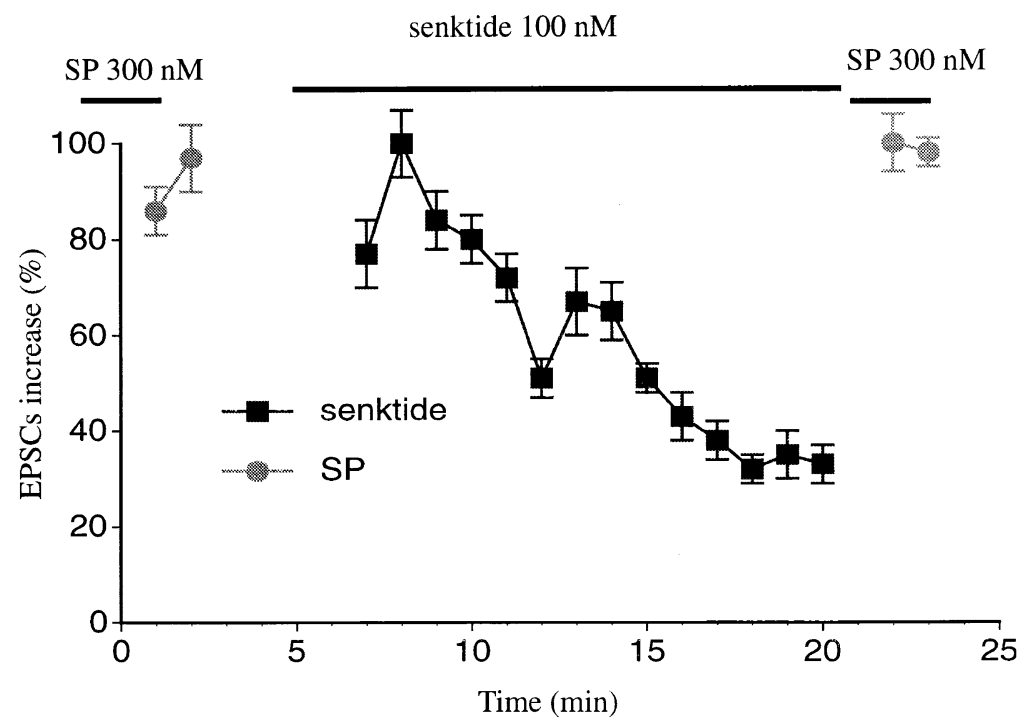

Figure 5. The induction of desensitization to the $\mathrm{NK}_{3}$ agonist senktide does not desensitize the response to the $\mathrm{NK}_{1}$ agonist SP. A. Intracellular recording from a cell under the following conditions: (1) baseline, (2) initial SP application (3) washout, (4) the initial period of senktide, (5) after continued senktide application (20 min), (6) SP application after senktide. B. Summarized data for five tested cells. Events were counted at $1 \mathrm{~min}$ intervals. Each point represents the mean of 5 neurons ( \pm SEM). Ten consecutive 1 -sec episodes were used to determine EPSC frequencies. Note that in preliminary experiments it had been determined that recovery of 5-HT neurons from desensitization to senktide did not begin until after $20 \mathrm{~min}$ or more of washout. Therefore, because the second SP application was given immediately after cessation of the senktide perfusion, the latter was not included in the SP solution.
DRN. Instead, the neurokinins were found to have an indirect excitatory effect on 5-HT neurons by inducing an increase in EPSCs in 5-HT neurons. The EPSCs were blocked by the AMPA/kainate glutamate receptor antagonist CNQX and were prevented by the fast $\mathrm{Na}^{+}$ channel blocker TTX, indicating an increase in impulse flow in local glutamatergic neuronal afferents. Previously, it has been shown that 5-HT neurons receive projections from local glutamatergic neurons present in the DRN slice preparation (Jolas and Aghajanian 1997). Consistent with the recent report of Froger and colleagues (Froger et al. 2001), no neurons were doubly immunostained for $5-\mathrm{HT}$ and for $\mathrm{NK}_{1}$ receptors despite the intermingling of 5 - $\mathrm{HT}$-positive and $\mathrm{NK}_{1}$-positive neurons within the DRN. The present results additionally show that there was no co-localization of 5-HT and $\mathrm{NK}_{3}$ receptors or $\mathrm{NK}_{1}$ and $\mathrm{NK}_{3}$ receptors. Taken together, the present results provide converging histochemical and electrophysiological evidence that neurokinins have a local excitatory influence upon 5-HT neurons, but that this effect is through an indirect rather than direct mechanism.

The present study provides several lines of evidence that SP and NKB are preferential agonists, respectively, for $\mathrm{NK}_{1}$ and $\mathrm{NK}_{3}$ receptors in the DRN. First, some neurons can be excited by SP but not by senktide, while other neurons are sensitive to senktide but not to SP. Second, low concentrations of the non-peptide $\mathrm{NK}_{1}$ receptor antagonist RP $67580(10 \mu \mathrm{M})$ reduced the SP-induced EPSCs but was inactive against NKB-induced EPSCs. Conversely, low concentrations of selective $\mathrm{NK}_{3}$ receptor antagonist SB $223412(10 \mu \mathrm{M})$ reduced NKBinduced but not SP-induced EPSCs. Third, minimal cross-desensitization occurred between SP and senktide. In addition, we found that the $\mathrm{NK}_{3}$ agonists generally were more efficacious in inducing EPSCs as well as increasing 5-HT firing rate (Table 1). In addition to this agonist selectivity, immunohistochemical double labeling showed that $\mathrm{NK}_{1}$ and $\mathrm{NK}_{3}$ receptors were not co-localized. This opens up the possibility that $\mathrm{NK}_{1}$ and $\mathrm{NK}_{3}$ 
The slower sweep trace Expanded time scale

A. phenylephrine $3 \mu \mathrm{M}$

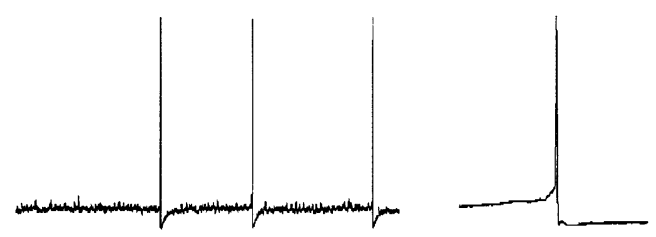

B. phenylephrine + senktide $100 \mathrm{nM}$
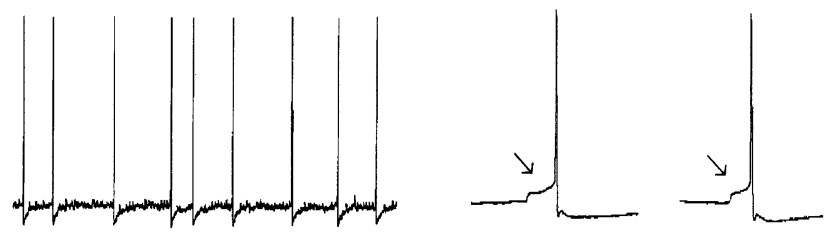

C. phenylephrine + CNQX $10 \mu \mathrm{M}$

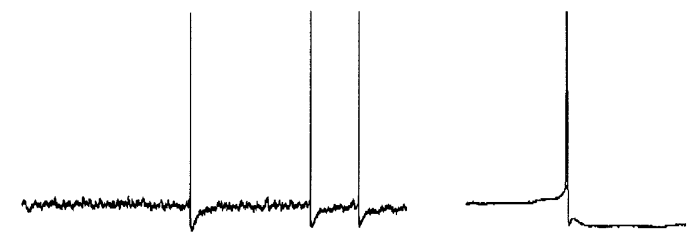

D. phenylephrine + CNQX $10 \mu \mathrm{M}+$ senktide $100 \mathrm{nM}$
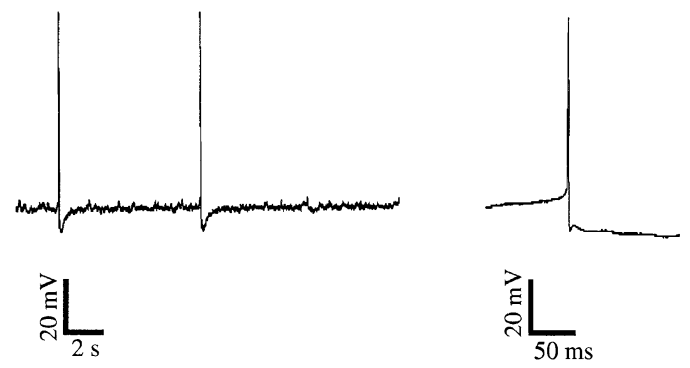

Figure 6. Senktide-induced EPSPs increase the spiking of 5-HT neurons. A. Intracellular recording from a 5-HT DRN neuron in which tonic firing was maintained by phenylephrine $(3 \mu \mathrm{M})$. Note, in the expanded time scale, that the spikes were triggered off slow depolarizing ramps (inset at right). B. Increase in action potential frequency induced by $100 \mathrm{nM}$ senktide. Note that in the presence of senktide, there was an emergence of spikes that were triggering by EPSPs rather than from depolarizing ramps (inset at right). C. CNQX did not decrease phenylephrine dependent spiking. D. The senktide-induced increase in spike frequency was blocked in the presence of CNQX.

receptive glutamatergic neurons could operate within independent circuits, as discussed below.

\section{Differences between the Local and Global Effects of Activating $\mathrm{NK}_{1}$ and $\mathrm{NK}_{3}$ Receptors}

As mentioned at the beginning of this article, in vivo studies show that there are differential effects of local versus intracisternal administration of $\mathrm{SP}$ and other $\mathrm{NK}_{1}$ agonists. While the injection of SP directly into the raphe nuclei leads to an increase 5-HT release and 5-HT-mediated behaviors, intracisternal administration of SP fails to elicit 5-HT-mediated behaviors (Gradin et al. 1992; Stoessl et al. 1987). In another in vivo study, it was found that the systemic administration of a SP $\left(\mathrm{NK}_{1}\right)$ antagonist produced an increase rather than a decrease in 5-HT cell firing (Santarelli et al. 2001), again indicating that SP does not have a global activating effect on the 5-HT system. The latter authors suggest that while our in vitro studies show a local activating effect of SP on 5-HT cell firing in brain slices, in intact preparations this is likely to be opposed by effects of SP elsewhere in the CNS. In contrast to $\mathrm{NK}_{1}$ agonists, the local and global effects of $\mathrm{NK}_{3}$ agonists are not different with respect to activating the 5-HT system. Behavioral studies show that $\mathrm{NK}_{3}$ agonists strongly elicit 5-HT mediated behaviors both after local injection into the raphe and after intracisternal administration. For example, the $\mathrm{NK}_{3}$ receptor agonist senktide strongly elicits 5-HT-mediated behaviors following both intracisternal (Stoessl et al. 1988) and local injections into the raphe nuclei (Paris et al. 1989). The latter results are consistent with our in vitro findings that the local application of $\mathrm{NK}_{3}$ albeit indirectly, activate 5-HT neurons in the DRN. Taken together, the in vivo and in vitro studies indicate that there are important differences between the overall influence of $\mathrm{NK}_{1}$ and $\mathrm{NK}_{3}$ receptors upon the 5-HT as well as other systems in the brain.

\section{Behavioral and Clinical Implications}

In a number of animal behavioral models, contrasting effects of $\mathrm{NK}_{1}$ and $\mathrm{NK}_{3}$ antagonists or agonists have been reported. Blockade of $\mathrm{NK}_{1}$ receptors has an anxiolyticlike effect in rats (File 1997) and mice (Teixeira et al. 1996; Santarelli et al. 2001), while stimulation of $\mathrm{NK}_{1}$ receptors by SP has an anxiogenic profile (Aguiar and Brandao 1996). The opposite behavioral profile has been observed after stimulation of $\mathrm{NK}_{3}$ receptors. For example, treatment of mice with the $\mathrm{NK}_{3}$ agonist $\mathrm{NKB}$ or senktide has an anxiolytic-like effect but the reverse effect is seen with an $\mathrm{NK}_{3}$ antagonist (Ribeiro et al. 1999). Thus, although SP and senktide are similar in activating 5-HT neurons, they differ in their overall effect in preclinical models of anxiety. As discussed above, these differences may result from actions of neurokinins in regions of the central nervous system outside of the DRN. These differences may be explained by the differing expression and distribution of $\mathrm{NK}_{1}$ and $\mathrm{NK}_{3}$ receptors in many regions of the brain (Lucas et al. 1992; Maeno et al. 1993; Ding et al. 1996). In addition, the present study shows that even within a single region such as the $\mathrm{DRN}, \mathrm{NK}_{1}$ and $\mathrm{NK}_{3}$ receptors do not necessarily co-localize on the same subpopulation of neurons. 
Given the contrasts between $\mathrm{NK}_{1}$ and $\mathrm{NK}_{3}$ receptors in animal model systems, it is likely that such differences will emerge in clinical situations. The $\mathrm{NK}_{1}$ receptor antagonist MK-869 has been reported to have therapeutic efficacy of in depressed patients (Kramer et al. 1998). As mentioned earlier, based on recent studies in NK1 knockout mice, it has been suggested the antidepressant effect of blocking NK1-receptors may result from desensitization/downregulation of $5-\mathrm{HT}_{1 \mathrm{~A}}$ autoreceptors (Froger et al. 2001). At this time, no information is available as to the effects of $\mathrm{NK}_{3}$ receptor antagonists or agonists in depression or other clinical disorders. $\mathrm{NK}_{3}$ receptor mRNA expression and receptor immunoreactivity have been found in human brain tissue (Buell et al. 1992; Mileusnic et al. 1999), providing a potential substrate for any therapeutic action of drugs targeting $\mathrm{NK}_{3}$ receptors. In view of the strong activating effects of $\mathrm{NK}_{3}$ agonists upon the 5-HT system, both locally and globally, further exploration into the role of 5-HT in clinical aspects of $\mathrm{NK}_{3}$ receptor function would be warranted.

\section{ACKNOWLEDGMENTS}

This work was supported by NIH Grants MH17871 and the State of Connecticut. We thank Ms. Nancy Margiotta who provided excellent technical assistance.

\section{REFERENCES}

Aghajanian GK, VanderMaelen CP (1982): Intracellular identification of central noradrenergic and serotonergic neurons by a new double labeling procedure. J Neurosci 2:1786-1792

Aghajanian GK, Lakoski JM (1984): Hyperpolarization of serotonergic neurons by serotonin and LSD: studies in brain slices showing increased $\mathrm{K}+$ conductance. Brain Res 305:181-185

Aguiar MS, Brandao ML (1996): Effects of microinjections of the neuropeptide substance $\mathrm{P}$ in the dorsal periaqueductal gray on the behaviour of rats in the plus-maze test. Physiol Behav 60:1183-1186

Baraban JM, Wang RY, Aghajanian G (1978): Reserpine suppression of dorsal raphe neuronal firing: mediation by adrenergic system. Eur J Pharmacol 52:27-36

Buell G, Schulz MF, Arkinstall SJ, Maury K, Missotten M, Adami N, Talabot F, Kawashima E (1992): Molecular characterization, expression and localization of human neurokinin-3 receptor. FEBS Lett 299:90-95

Burlhis TM, Aghajanian GK (1987): Pacemaker potentials of serotonergic dorsal raphe neurons: contribution of a low-threshold $\mathrm{Ca}^{2+}$ conductance. Synapse 1:582-588

Chaput Y, de Montigny C, Blier P (1986): Effects of a selective 5-HT reuptake blocker, citalopram, on the sensitivity of 5-HT autoreceptors: electrophysiological studies in the rat brain. Naunyn Schmiedebergs Arch Pharmacol 333:342-348
Cuello AC, Kanazawa I (1978): The distribution of substance $\mathrm{P}$ immunoreactive fibers in the rat central nervous system. J Comp Neurol 178:129-156

Culman J, Unger T (1995): Central tachykinins: mediators of defense and stress reactions. J Physiol Pharmacol 73:885-891

Dahlström A, Fuxe K (1964): Evidence for the existence of monoamine-containing neurons in the central nervous system. I. Demonstration of monoamines in the cell bodies of brain stem neurons. Act Physiol Scand 62:1-55

Ding YQ, Shigemoto R, Takada M, Ohishi H, Nakanishi H, Mizuno N (1996): Localization of the neuromedin K receptor $\left(\mathrm{NK}_{3}\right)$ in the central nervous system of the rat. J Comp Neurol 364:290-310

File SE (1997): Anxiolytic action of a neurokinin receptor antagonist in the social interaction test. Pharmacol Biochem Behav 58:747-752

Fong TM, Yu H, Strader CD (1992): Molecular basis for the species selectivity of the neurokinin-1 receptor antagonists CP-96,345 and RP67580. J Biol Chem 267:2566825671

Forchetti CM, Marco EJ, Meek JL (1982): Serotonin and gamma-aminobutyric acid turnover after injection into the median raphe of substance $\mathrm{P}$ and D-Ala-Metenkephalin amide. J Neurochem 38:1336-1341

Froger N, Gardier AM, Moratalla R, Alberti I, Lena I, Boni C, De Felipe C, Rupniak NM, Hunt SP, Jacquot C, Hamon M, Lanfumey L (2001): 5-hydroxytryptamine (5-HT)1A autoreceptor adaptive changes in substance $\mathrm{P}$ (neurokinin 1) receptor knock-out mice mimic antidepressantinduced desensitization. J Neurosci 21:8188-8197

Gallager DW, Aghajanian GK (1976): Effect of antipsychotic drugs on the firing of dorsal raphe cells. I. Role of adrenergic system. Eur J Pharmacol 39:341-355

Garret C, Carruette A, Fardin V, Moussaoui S, Peyronel JF, Blanchard JC Laduron PM (1991): Pharmacological properties of a potent and selective nonpeptide substance P antagonist. Proc Natl Acad Sci USA 88:208-212

Goodman LA (1954): Kolmogorov-Smirnov tests for psychological research. Psychol Bull 51:160-168

Gradin K, Qadri F, Nomikos GG, Hillegaart V, Svensson TH (1992): Substance P injection into the dorsal raphe increases blood pressure and serotonin release in hippocampus of conscious rats. Eur J Pharmacol 218:363367

Horwell DC (1995): The 'peptoid' approach to the design of nonpeptide, small molecule agonists and antagonists of neuropeptides. TIBTECH 13:132-134

Iversen LL, McNight AT, Foster AC, Young SC, Williams BJ (1990): Pharmacology of the tachykinin system. In Schwartz TW, Hilsted LM, Rehfeld JF (eds), Neuropeptides and Their Receptors. Copenhagen, Munksgaard, pp 363-372

Jolas T, Aghajanian GK (1996): Neurotensin excitation of serotonergic neurons in the dorsal raphe nucleus of the rat in vitro. Eur J Neurosci 8:153-161

Jolas T, Aghajanian GK (1997): Opioids suppress spontaneous and NMDA-induced inhibitory postsynaptic currents in the dorsal raphe nucleus of the rat in vitro. Brain Res 755:229-245 
Kramer MS, Cutler N, Feighner J, Shrivastava R, Carman J, Sramek JJ, Reines SA, Liu G, Snavely D,Wyatt-Knowles E, Hale JJ, Mills SG, MacCoss M, Swain CJ, Harrison T, Hill RG, Hefti F, Scolnick EM, Cascieri MA, Chicchi GG, Sadowski S, Williams AR, Hewson L, Smith D, Carlson EJ, Hargreaves RJ, Rupniak NM (1998): Distinct mechanism for antidepressant activity by blockade of central substance P receptors. Science 281:1640-5

Laufer R, Gilon C, Chorev M, Selinger Z (1986a): Characterization of a neurokinin $B$ receptor site in rat brain using a highly selective radioligand. J Biol Chem 261:10257-10263

Laufer R, Gilon C, Chorev M, Selinger Z (1986b): [pGlu6,Pro9]SP6-11, a selective agonist for the substance P P-receptor subtype. J Med Chem 29:1284-1288

Laufer R, Gilon C, Chorev M, Selinger Z (1988): Desensitization with a selective agonist discriminates between multiple tachykinin receptors. J Pharmacol Exp Ther 245:639-643

Lucas LR, Hurley DL, Krause JE, Harlan RE (1992): Localization of the tachykinin neurokinin B precursor peptide in rat brain by immunocytochemistry and in situ hybridization. Neuroscience 51:317-345

Maeno H, Kiyama H, Tohyama M (1993): Distribution of the substance $\mathrm{P}$ receptor (NK-1 receptor) in the central nervous system. Mol Brain Res 18:43-58

Maggi CA, Patacchini R, Rovero P, Giachett A (1993): Tachykinin receptors and tachykinin receptor antagonists. J Auto Pharmacol 13:23-93

Marksteiner J, Sperk G, Krause JE (1992): Distribution of neurons expressing neurokinin $\mathrm{B}$ in the rat brain: immunohistochemistry and in situ hybridization. J Comp Neurol 317:341-356

Mileusnic D, Lee JM, Magnuson DJ, Hejna MJ, Krause JE, Lorens JB, Lorens SA (1999): Neurokinin-3 receptor distribution in rat and human brain: An immunohistochemical study. Neuroscience 89:1269-1290

Nakanishi S (1991): Mammalian tachykinin receptors. Annu Rev Neurosci 14:123-136

Paris JM, Lorens SA (1987): Intra-median raphe infusions of muscimol and the substance $\mathrm{P}$ analogue DiMe-C7 produce hyperactivity: role of serotonin neurons. Behav Brain Res 26:139-151

Paris JM, Mitsushio H, Lorens SA (1989): Intra-raphe neurokinin-induced hyperactivity: effects of 5,7-dihydroxytryptamine lesions. Brain Res 476:183-188

Regoli D, Boudon A, Fauchere JL (1994): Receptors and antagonists for substance P related peptides. Pharmacol Rev 46:551-599

Reisine T, Soubrie P, Artaud F, Glowinski J (1982): Application of L-glutamic acid and substance P to the substantia nigra modulates in vivo $\left[{ }^{3} \mathrm{H}\right]$ serotonin release in the basal ganglia of the cat. Brain Res 236:317-327

Reubi JC, Emson PC, Jessell TM, Iversen LL (1978): Effects of GABA, dopamine, and substance $P$ on the release of newly synthesized ${ }^{3} \mathrm{H}-5$-hydroxytryptamine from rat substantia nigra in vitro. Naunyn Schmiedebergs Arch Pharmacol 304:271-275

Ribeiro SJ, Teixeira RM, Calixto JB, De Lima TC (1999):
Tachykinin NK(3) receptor involvement in anxiety. Neuropeptides 33:181-188

Santarelli L, Gobbi G, Debs PC, Sibille ET, Blier P, Hen R, Heath MJ (2001): Genetic and pharmacological disruption of neurokinin 1 receptor function decreases anxiety-related behaviors and increases serotonergic function. Proc Natl Acad Sci USA 98:1912-1917

Sarau HM, Griswold DE, Potts W, Foley JJ, Schmidt DB, Webb EF, Martin LD, Brawner ME, Elshourbagy NA, Medhurst AD, Giardina GA, Hay DW (1997): Nonpeptide tachykinin receptor antagonists: I. Pharmacological and pharmacokinetic characterization of SB 223412, a novel, potent and selective neurokinin-3 receptor antagonist. J Pharmacol Exp Ther 281:1303-1311

Seabrook GR, Bowery BJ, Hill RG (1995): Pharmacology of tachykinin receptors on neurons in the ventral tegmental area of rat brain slices. Eur J Pharmacol 273:113-119

Shindler KS, Roth KA (1996): Double immunofluorescent staining using two unconjugated primary antisera raised in the same species. J Histochem Cytochem 44:1331-1335

Solti M, Bartfai T (1987): Tachykinin regulation of serotonin release: enhancement of $\left[{ }^{3} \mathrm{H}\right]$ serotonin release from rat cerebral cortex by neuromedin $\mathrm{K}$ and substance $\mathrm{P}$ acting at distinct receptor sites. Brain Res 401:377-380

Stables JM, Beresford IJ, Arkinstall S, Ireland SJ, Walsh DM, Seale PW, Ward P, Hagen RM (1994): GR 138676, a novel peptidic tachykinin antagonist which is potent at $\mathrm{NK}_{3}$ receptors. Neuropeptides 27:333-341

Stoessl AJ, Dourish CT, Young SC, Williams BJ, Iversen SD, Iversen LL (1987): Senktide, a selective neurokinin Blike agonist, elicits serotonin-mediated behaviour following intracisternal administration in the mouse. Neurosci Lett 80:321-326

Stoessl AJ, Dourish CT, Iversen SD (1988): The NK-3 tachykinin receptor agonist senktide elicits 5-HT-mediated behaviour following central or peripheral administration in mice and rats. Br J Pharmacol 94:285-287

Stoessl AJ, Dourish CT, Iversen SD (1990): Pharmacological characterization of the behavioural syndrome induced by the NK-3 tachykinin agonist senktide in rodents: evidence for mediation by endogenous 5-HT. Brain Res 517:111-116

Stout SC, Owens MJ, Nemeroff CB (2001): Neurokinin receptor antagonists as potential antidepressants. Annu Rev Pharmacol Toxicol 41:877-906

Teixeira RM, Santos AR, Ribeiro SJ, Calixto JB, Rae GA, De Lima TC (1996): Effects of central administration of tachykinin receptor agonists and antagonists on plusmaze behavior in mice. Eur J Pharmacol 311:7-14

Ungerstedt U (1971): Stereotaxic mapping of the monoamine pathways in the rat brain. Acta Physiol Scand (Suppl 367):1-48

VanderMaelen CP, Aghajanian GK (1983): Electrophysiological and pharmacological characterization of serotonergic dorsal raphe neurons recorded extracellularly and intracellularly in rat brain slices. Brain Res 289:109-119

Wormser U, Laufer R, Hart Y, Chorev M, Gilon C, Selinger Z (1986): Highly selective agonists for substance $P$ receptor subtypes. EMBO J 5:2805-2808 